\title{
New Bryozoa from the Sarmatian (Middle Miocene) deposits of the Cerna-Strei Depression, Romania
}

\author{
Kamil ZÁGORŠEK ${ }^{*}$, Lóránd SILYE ${ }^{2}$ \& Botond SZABÓ ${ }^{2}$ \\ ${ }^{1}$ National Museum, Václavské nám. 68, CZ - 11579 Praha 1, Czech Republic \\ ${ }^{2}$ Department of Geology, „Babeş-Bolyai” University, Kogălniceanu 1, 400084 Cluj Napoca, Romania
}

Received February 2008; accepted July 2008

Available online 25 August 2008

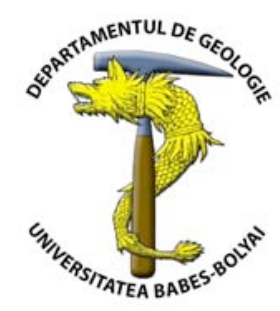

\begin{abstract}
A new species of the Sarmatian bryozoan, Crisia romanica sp. nov., is described from Sarmatian (Middle Miocene) sediments of the Cerna-Strei Depression, near Răcăştia, Romania. The new species differs from all other known species of Crisia by having a frontal elongated gonozooecium with a prominent oeciopore situated on a short oeciostome. Crisia romanica sp. nov. is accompanied by Annectocyma corrugata (REuss, 1869) occurring in a section nearby. The bryozoans found indicate normal marine conditions in the Cerna-Strei Depression during the Sarmatian.
\end{abstract}

Key words: Bryozoa, taxonomy, new species, Sarmatian, Middle Miocene.

\section{INTRODUCTION}

The first systematic account of the early Sarmatian (late Middle Miocene) bryozoans from Romania was prepared by Ghiurcă and Stancu (1974). They described a small number of species, such as Annectocyma corrungata (REUSS, 1869), Schizoporella montifera (ULRICH and BASSLER, 1904), Cryptosula terebrata (SINZOV, 1892), and Crisiella carnuntina BOBIES, 1957, from the following Romanian localities: Benesad, Berca, Buciumi, Copăcel, Morilor, Soceni, Trestia, Tusa, Valea, and Valea Politonai.

New sections with Sarmatian bryozoans were discovered in the vicinity of Răcăştia (Hunedoara County). The area was described in details by Gaál (1911), who however, did not report any bryozoans from there. During recent field work two of us (LS and BSz) examined these outcrops and found rare fragments of bryozoans.

Although these bryozoan assemblages are characterized by very low diversity (only two taxa could be identified), one of their components is a new species of Crisia.

In our opinion, the identification of these taxa is very important for deciphering the Sarmatian palaeogeography of Carpathian-Pannonian system, and fits very well to the results of the recent studies published by Fordinál et al. (2006), Zágoršek (2007), and Zágoršek and Fordinál (2006).

\section{GEOLOGICAL BACKGROUND}

In the studied area (Fig 1), the outcropping sediments are mainly fine to coarse-grained Middle Miocene (Badenian and Sarmatian) siliciclastics (Koch, 1900; Halaváts, 1903; Gaál, 1911; Popescu, 1977), however in the neighbourhoods of Răcăştia some small patches of Sarmatian limestones also occur (Halaváts, 1903; Gaál, 1911).
According to Gaál (1911) the thickness of the sediments around Răcăştia is about $170 \mathrm{~m}$, and it was deposited during the Early Sarmatian in continental (e.g., fresh water) to shallow water brackish environments.

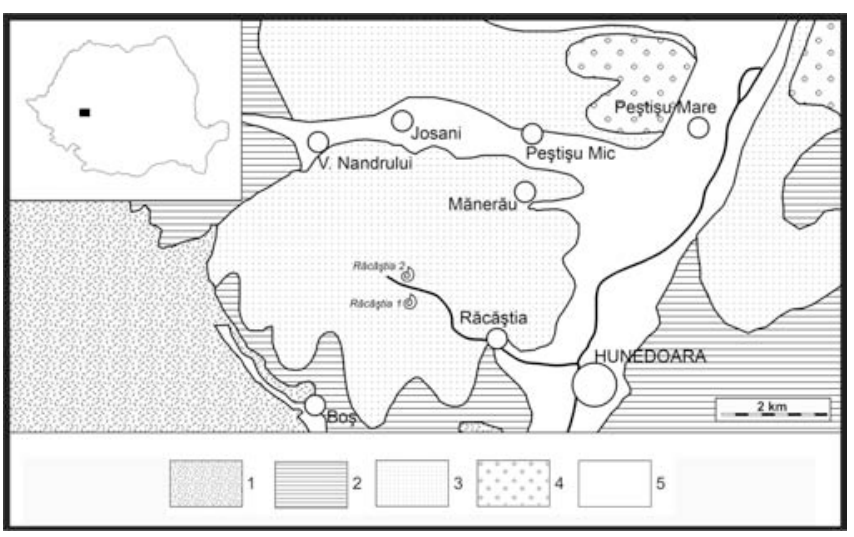

Fig. 1. Simplified geological map showing the location of sampled outcrops: 1. metamorphic rocks, 2. Badenian, 3. Sarmatian, 4. Pleistocene, 5. Holocene (based on Gherasi et al., 1968).

\section{MATERIALS AND METHODS}

We collected five samples (numbered 1-5) from Răcăştia 1 and four samples (numbered 6-9) from Răcăştia 2 (see Fig. 2). They were processed by standard methods, i.e. dried, boiled in water with sodium carbonate $\left(\mathrm{Na}_{2} \mathrm{CO}_{3}\right)$, and then washed over a $63-\mu \mathrm{m}$ sieve. The bryozoans (and other fossils i.e. foraminifers, ostracods, and molluscs), were picked from the $>63-\mu \mathrm{m}$ residue, and photographed using a JEOL JSM 5510 LV scanning electron microscope at Electron Microscopic Centre, „Babeş-Bolyai” University, Cluj Napoca, Romania. 


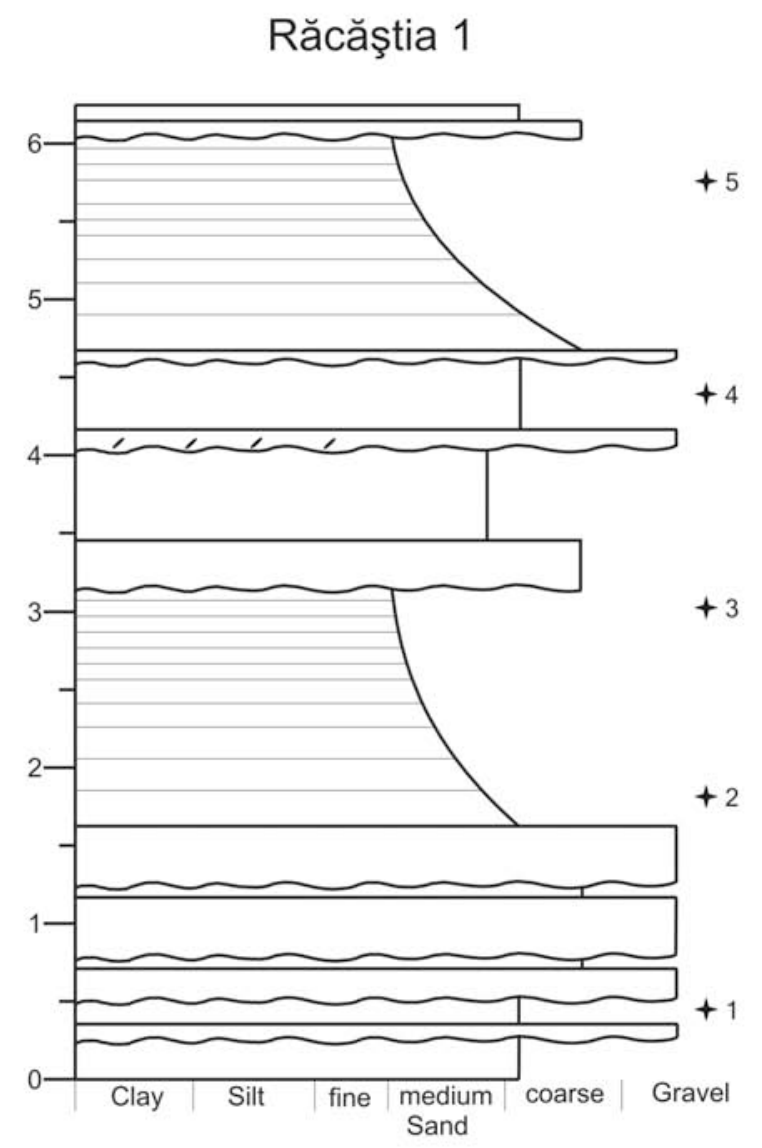

\section{Răcăştia 2}

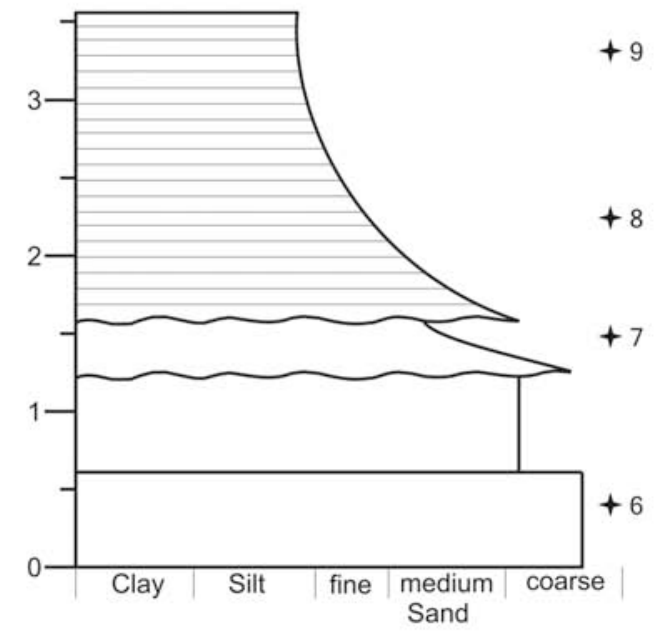

Fig. 2. Lithological section of the studied localities. Position of samples indicated by asterisks and numbers (for detailed explanations concerning lithology see the text).

\section{RESULTS}

\section{Studied localities}

Two small outcrops (Răcăştia 1 and 2) were accessible near Răcăştia for micropaleontological sampling during autumn 2007. Their sedimentological records resemble the characteristics of the $\mathrm{VI}^{\text {th }}$ (Răcăştia 1, and the lower part of Răcăştia 2), and VII ${ }^{\text {th }}$ (the upper part of Răcăştia 2) layers of Gaál (1911).

Răcăştia 1 is located at $45^{\circ} 46^{\prime} 23.477952^{\prime \prime} \mathrm{N}$, $22^{\circ} 511^{\prime} 52.791624^{\prime \prime} \mathrm{E}$, on the right side of a creek which crosses Răcăştia (Fig. 1).

The section is about $6 \mathrm{~m}$ high, and is made up of coarse to fine grain siliciclastics i.e., sand to gravel (Fig. 2). The coarse sand to gravel units (mostly incised gravel filled lags with erosional lower boundaries, and sometimes contain ripup clasts) are dominant at the base of the section. The upper part of the section is formed by thin layers of fine to medium grain sand. The thickness of the layers is about 5 $10 \mathrm{~cm}$.

Moreover, at least two well-developed fining upward parasequences can be recognized at this section.
Răcăştia 2 is located at $45^{\circ} 46^{\prime} 28.609392^{\prime \prime} \mathrm{N}$, $22^{\circ} 51$ '52.305588 “E, about 200 m north-west from Răcăştia 1 , on the side of road, which leads to Nandrului Valley (Fig. 1). At this outcrop (Figs. $2 \& 3$ ) three sedimentary units can be recognized:

- a lower unit formed by massive coarse grained sandstones, rich in randomly distributed gastropods (mainly Cerithium);

- the middle unit, which consists of thin bedded fine to medium sandstone, interrupted at the middle part by small lags;

- an upper unit which consist of a fining upward series of medium-size grain sands to clayish fine silts.

\section{Fossil content and palaeoecology}

Calcareous benthic foraminifera fauna are known from both outcrops, which are dominated at Răcăştia 1 by species of Ammonia, and Elphidum, whilst at Răcăştia 2 the species diversity is higher because miliolids are also present.

These assemblages belong to the Elphidium regium Biozone (Popescu, 1995) and indicate an Early Sarmatian shallow-water depositional environment for the studied samples (Silye and Szabó, 2007). 


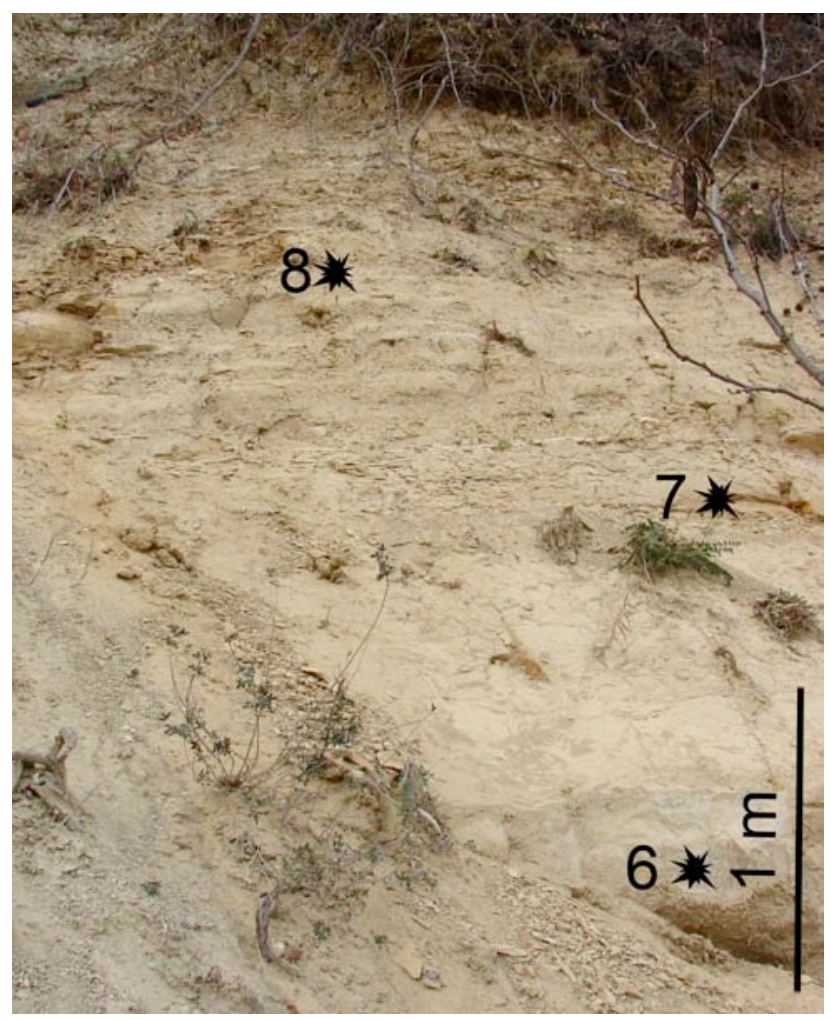

Fig. 3. Photograph of section Răcăştia 2, showing the main lithological features and the position of the samples 6 to 8 .

\section{Systematic Palaeontology}

Phylum Bryozoa EHRENBERG, 1831

Class Stenolaemata BoRG, 1926

Order Cyclostomatida BUSK, 1852

Suborder Articulata BUSK, 1859

Family Crisiidae JOHnSTON, 1838

Genus Crisia LAMOUROUX, 1812

Crisia romanica nov. sp. (Plate 1, Figs. 1-5)

1958 Crisia eburnea (Lin.) - Bobies p. 151, pl. 13, Figs. 2-3.

Diagnosis: Colony erect. Zooecial tubes long, no more than two tubes one to each other forming the colonial branch, with terminal aperture. The gonozooecium is small, elongated, with a terminal ooeciostome.

Holotype: Specimen from Răcăştia 2, sample 7, illustrated on Pl. 1, Fig. 1 and 2, deposited in the collection of the Museum of Paleontology, Department of Geology, „Babeş-Bolyai” University, Cluj Napoca, under the registration number 23483.

Paratypes: Four specimens from Răcăştia 2, sample 7, depicted on Pl. 1, Figs. 3 - 5, deposited in the collection of the Museum of Department of Geology, „Babeş-Bolyai” University, Cluj-Napoca, under the registration number 23484.

Other specimens are deposited in authors' collections.

Derivatio nominis: After the name of the country Romania.

Locus typicus: Răcăştia, Hunedoara County, Romania.

Stratum typicum: Lower Sarmatian (Middle Miocene) fine-medium grained sands.

Dimensions:

- length of the preserved part of the colony: 1266-1847 $\mu \mathrm{m}$;
- maximum width of the preserved part of the colony: average $217 \mu \mathrm{m}$;

- maximum width of the zooecial tubes: $157 \mu \mathrm{m}$;

- distance between apertures: 430-807 $\mu \mathrm{m}$

- diameter of the apertures: 77-97 $\mu \mathrm{m}$

- length of gonozooecium: $405 \mu \mathrm{m}$

- width of gonozooecium: $238 \mu \mathrm{m}$

- diameter of oeciopore: $63 \mu \mathrm{m}$

- length of ooeciostome: 87-101 $\mu \mathrm{m}$

Description: Colony erect. The preserved parts of the colony consist always of 4-5 zooecial tubes, which suggest articulate structure of the colony and flexible growth form. The width of the colonial branch (internode) is about 0.2 $\mathrm{mm}$, which is about one and half the width of a zooecial tube. Zooecial tubes are long, with alternating terminal apertures. No more than two tubes are arranged one to each other, base of internode is formed by only one tube. Apertures are circular, situated on the top of the peristome slightly being curved laterally from the colony branch axis. The zooecial frontal wall is smooth, slightly ribbed and little convex. The dorsal wall is smooth, porous and convex.

Gonozooecia are small, oval with width little larger than the width of the colonial branch. The gonozooecium is situated in the lower half of the branch on the frontal wall of the autozooecial tube. The circular to slightly oval oeciopore is situated on the top of the terminal ooeciostome, slightly curved from the branch axis.

Comparison: The most similar species is Crisia eburnea (LINNAEUS, 1758), which has almost similar structure of the colony (one to two autozooecial tubes forming the colonial branch), but differs in having a much larger gonozooecium with short ooeciostome.

An other similar species is Crisiella carnuntina BOBIES, 1957 as described in Bobies (1957), p. 92, P1. 9, Figs. 19-20. It differs mainly in having the gonozooecium situated at the top of the colonial branch between autozooecial apertures. Moreover, Crisiella carnuntina BOBIES, 1957 developed larger colonies with sometimes more than three zooecial tubes one to each other.

Crisia eburnea as described by Bobies (1958) shows same characteristic features as established new species. Although we are unable to find the original material of Bobies (personal investigation of $\mathrm{KZ}$ and personal communication with Prof. Vavra and Dr. Ostrovsky), the photography (mainly shape of the gonozooecium and ooeciopore) of the Bobies specimen allows us to include it in our new species.

Remarks: Although the growth form of the Crisia romanica sp. nov. is not certain, the general habitus is very similar to the species of Crisia and therefore it is listed under this name.

Suborder Tubuliporina MILNE EDWARDS, 1838

Family Annectocymidae HAYWARD \& RYLAND, 1985

Genus Annectocyma HAYWARD \& RYLAND, 1985

Annectocyma corrugata (REUSS, 1869). Plate 1, Fig. 6

1869 Distopora corrugata m., Reuss p. 510-511, Pl. 1, Figs. 6-7, Pl. 2, Figs. 1-5.

1957 Distopora corrugata REUSS, Bobies p. 93, Pl. 10, Figs. 25-26.

1974 Distopora corrugata REUSS, Ghiurcă and Stancu p. 303, P1. 1, Figs. 3-4. 
Material: Two specimens, found at Răcăştia 1, in the medium-fine sands of sample 3 and 5 .

Diagnosis: The preserved part of the colony is erect, unilamellar with 5 to 10 zooecial rows obliquely parallel to each other. The zooecial tubes are short. The apertures are circular, situated on a short but wide peristome. The gonozooecium is situated on the proximal end of the colony. It is large with porous frontal wall, spread between 3 to 4 autozooecial tubes. The oeciopore has not been preserved. The dorsal wall of the colony is smooth.

Remarks: Because of the encrusting base, chaotic growth of zooecial tubes and gonozooecium situated on the top of the colony it resembles very much the genus Annectocyma, even no ancenstrula have been found.

The type specimen illustrated by REUSS shows almost identical growth pattern, but does not show a developed gonozooecium. Gonozooecium have been described by Bobies (1957), which is identical with those found in Romanian specimen.

The species is similar to Tubulipora cumulus SINZOV, 1892 as described by Zágoršek and Fordinál (2006), but differs in having unilamellar growth form and in shape and the position of the gonozooecia.

Occurrence: Already reported from Romania from the localities Soceni and Valea Politonai (Ghiurcă and Stancu, 1974).

\section{CONCLUSIONS}

Crisia romanica sp. nov. a new species of Sarmatian Bryozoa has been described from sediments of the Cerna-Strei Depression, near Răcăştia, Romania. The new species differs from all other fossil known species of Crisia by having a frontal small, oval gonozooecium with prominent ooeciostome.

The bryozoans found as well as the associated foraminiferal assemblages are typical components of a normal marine fauna (Zágoršek and Fordinál, 2006), which leads us to point out, that the character of the environment of the Cerna-Strei Depression, near Răcăştia (Romania) was probably normal shallow-marine during Early Sarmatian. This result is contrary to conclusions of Gaál (1911), who suggested brackish water environments for the same strata. As shown by recent palaeoecological and isotopic studies (Latal et al., 2004; Piller and Harzhauser, 2005; Fordinál et al., 2006), normal marine conditions during Sarmatian can be expected also in neighbour countries (Slovakia, Austria).

Acknowledgements. Kamil Zágoršek is grateful for the financial support received from Project of Ministry of Culture of Czech Republic DE06P04OMG009, whilst Lóránd Silye thanks the Cushman Foundation for Foraminiferal Research (William V. Sliter Award), and CNCSIS Romania (grant TD 411/2006) for their substantial help. The research was partly supported also by projects P19337-B17 and 205/06/0637. The help of Franz Wanek as regards the location of outcrops arround Răcăştia is also greatly appreciated. We express out thanks to the Prof. Vavra, Dr. Ostrovsky, and an anonymous reviewer for their help with very valuable comments and searching for Bobies material.

\section{R E F E R E N C E S}

Bobies C. 1957, Bryozoenstudien II. Die Bryozoen des österreichischen Sarmats. Jahrbuch der Geologischen Bundesanstalt, 100 (1): 81-112.

Bobies C. 1958, Bryozoenstudien III/1. Die Crisiidae (Bryozoa) des Tortons im Wiener Becken. Jahrbuch der Geologischen Bundesanstalt, 101 (1): 147-165.

Fordinál, K., Zágoršek, K. \& Zlínská, A. 2006, Early Sarmatian biota in the northern part of the Danube Basin (Slovakia). Geologica Carpathica, 57 (2): 123 - 130.

Gaál, I. 1911, A Hunyadmegyei Rákosd szarmatakorú csigafaunája. A Magyar Királyi Földtani Intézet Évkönyve, XVIII (1): 1-97.

Gherasi, N., Mureşan, M., Mureşan, G., Kräutner, F., Kräutner, H., Lupu, M., Marinescu, F., Savu, H. \& Arghir-Drăgulescu, A. 1968, Harta Geologică a RSR, foaia 25 Deva, scara 1:200.000. Institutul de Geologie şi Geofizică, Bucureşti.

Ghiurcă, V., Stancu, J. 1974, Les Bryozoaires sarmatiens du Paratethys Central. In M5 Sarmatien (sensu E. Suess 1866). Die Sarmatische Schichtengruppe und ihr Stratotypus. (Brestenská, E., Ed.), VEDA, Chronostratigraphie und Neostratotypen. Miozän der Zentralen Paratethys, IV: 298-317, Bratislava.

Halaváts, Gy. 1903, Vajda-Hunyad környékének földtani alkotása. A Magyar Királyi Földtani Intézet Évi Jelentése 1902-röl, p. 83-89.

Koch, A. 1900, Az erdélyrészi medencze harmadkori képzödményei. II. Neogén csoport. Magyarhoni Földtani Társulat, Budapest, p. 329.

Latal, C., Piller, W.E. \& Harzhauser, M. 2004, Palaeoenvironmental reconstructions by stable isotopes of Middle Miocene gastropods of Central Paratethys. Palaeogeography, Palaeoclimatology, Palaeoecology, 211 (1-2): 157-169.

Piller, W.E., Harzhauser M. 2005, The myth of the brackish Sarmatian Sea. Terra Nova, 17(5): 450-455.

Popescu, G. 1977, Date preliminare asupra foraminiferelor Miocenului mediu din împrejurimile Hunedoarei. Dări de Seamă ale Şedinţelor Institutul de Geologie şi Geofizică, LXIII (3): 63-71.

Popescu, G. 1995, Contribution to the knowledge of the Sarmatian Foraminifera of Romania. Romanian Journal of Paleontology, 76: 85-98.

Reuss, A.E. 1869, Über tertiäre Bryozoen von Kischenew in Bessarabien. Sitzungberichte der kaiserlichen Akademie der Wissenschaften, 60: 505-513.

Silye, L., Szabó, B. 2007, Lower Sarmatian microfauna from Răcăştia (Hunedoara Country). Annual Scientific Session „Ion Popescu Voiteşti”, Programme and Abstracts, p. 50, Cluj-Napoca.

Zágoršek, K., Fordinál, F. 2006, Lower Sarmatian Bryozoa from brackish sediment in the northern part of the Danube Basin (Dubová, Slovakia). Linzer biologische Beiträge, 38 (1): 93-99.

Zágoršek, K. 2007, A new Miocene Bryozoa from the Sarmatian of the Danube basin. Neues Jahrbuch für Geologie und Paläontologie - Abhandlungen, 243 (3): 299-303. 
PLATE I

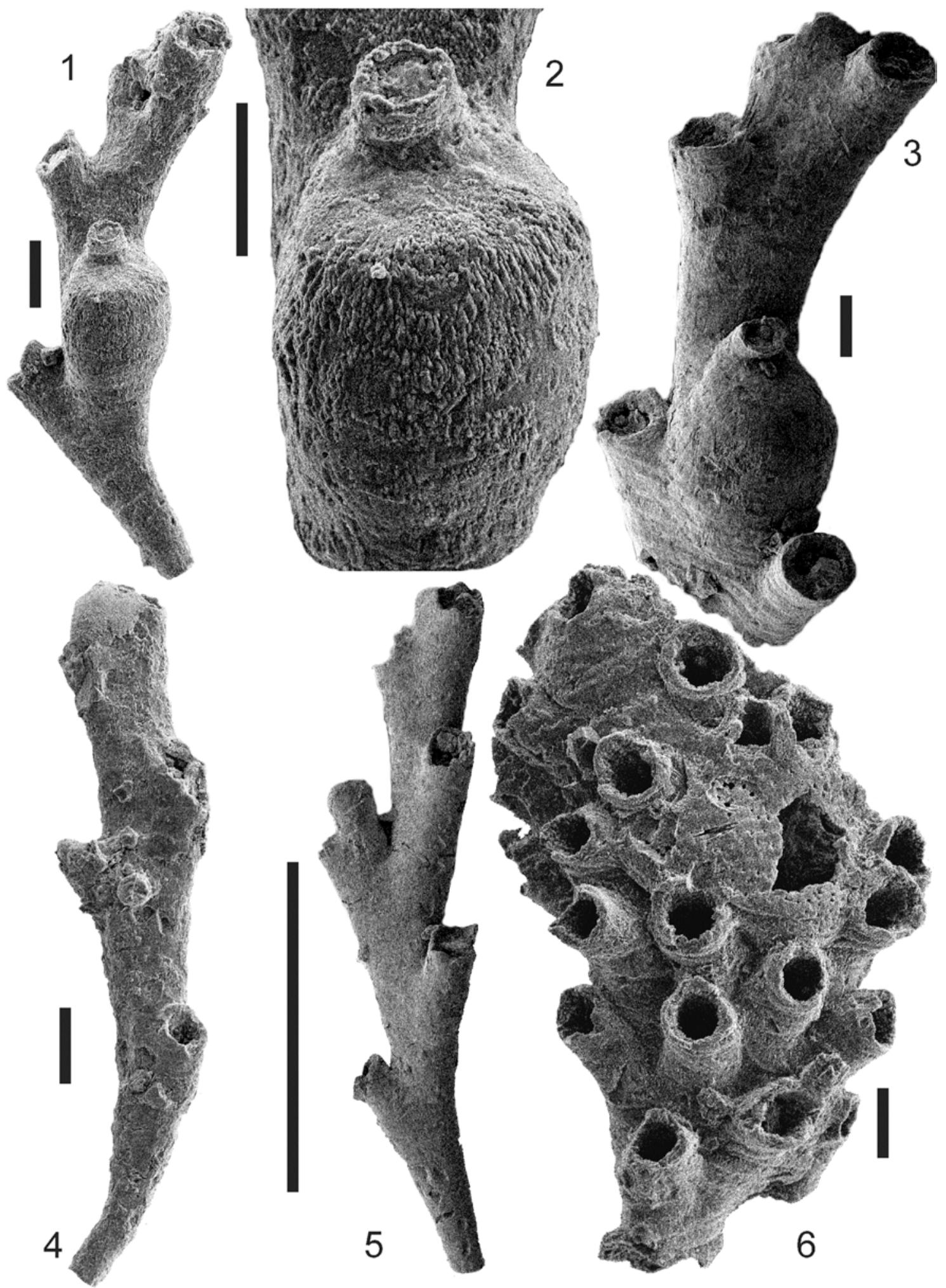

Plate I. Crisia romanica sp. nov. from the Răcăștia 2, sample 7

Fig. 1. General view of the holotype (registration number 23483) development of gonozooecium. Scale bar $1 \mathrm{~mm}$.

Fig. 2. Detail of the gonozooecium of the holotype showing elongated ooeciostome with oeciopore. Scale bar $100 \mu \mathrm{m}$.

Fig. 3. General view of paratype (registration number 23484) showing gonozooecium with showing slightly curved ooeciostome and oeciopore. Scale bar $1 \mathrm{~mm}$.

Fig. 4. General view of paratype (registration number 23484) showing alternating autozooecial tubes. Scale bar $100 \mu \mathrm{m}$.

Fig. 5. Frontal view of paratype (registration number 23484) showing denser alternating autozooecial tubes. Scale bar $1 \mathrm{~mm}$.

Fig. 6. Annectocyma corrugata (REUSS, 1869). General view of specimen from the Răcăştia 1, sample 5 showing development of gonozooecium. Scale bar $1 \mathrm{~mm}$. 